\title{
Música y alameda en la Edad Moderna: el caso de la sevillana alameda de Hércules en el siglo XVIII*/
}

\author{
Music and Boulevard in Early Modern Age: the Case of \\ Sevillian Alameda de Hércules in the XVIIIth Century
}

Clara Bejarano Pellicer

Universidad de Sevilla

El propósito de este artículo es la aproximación al fenómeno musical de recreo al aire libre en la sociedad urbana del siglo XVIII, así como a su contribución a la creación de un espacio público de sociabilidad abierto a todos los estamentos. Se aborda el estudio de caso de la alameda de Hércules de Sevilla como el más inmediato modelo que inspiró a las alamedas americanas.

Palabras Clave: Música; Alameda; Paseo; Sociabilidad; Ministriles; Sevilla.

The purpose of this paper is the approximation to amusement music outdoors in the urban society in XVIIIth century, and also its contribution to the creation of a public space for sociability in reach for all the classes. The alameda de Hércules of Seville is taken as a case study because it was the closest inspiration for American boulevards.

KeY words: Music; Boulevard; Promenade; Sociability; Minstrels; Seville.

* Trabajo que se inscribe en el Proyecto I+D «Andalucía en el mundo atlántico: actividades económicas, realidades sociales y representaciones culturales (siglos XVI-XVIII)». HAR2013-41342P. Dicho proyecto está financiado por la Subdirección General de Proyectos de Investigación del Ministerio de Economía y Competitividad. 
La eclosión de las alamedas y paseos públicos, tanto en urbanismo como en sociabilidad, tuvo lugar en el Siglo de las Luces, preferentemente en el último tercio de la centuria. Estos espacios no solo supusieron un aporte a la historia del urbanismo y permitieron la expansión de las actividades de ocio, sino que también contribuyeron a la sociabilidad en la segunda mitad del siglo XVIII e inicios del XIX, y al convencimiento de avance y progreso social. Incluso están relacionados con el desarrollo del orgullo local. ${ }^{1}$ En estas fechas, la civilización occidental había conocido un importante avance en la inserción de la audición y la práctica musical en la vida cotidiana, tanto en la esfera privada, como en la semiprivada y la pública. Por lo tanto, no es de extrañar que las formas de sociabilidad que propiciaron la construcción de las alamedas casaran cabalmente con un recurso habitual a las actividades musicales en espacios públicos. No obstante, remontándose a la Alta Modernidad se descubre que ambos fenómenos y su relación entre sí tienen raíces muy anteriores al espíritu ilustrado y a la generalización del consumo musical.

Los estudios sobre música y sociabilidad han tenido su ámbito preferente en la cronología decimonónica, gracias a la disponibilidad de ricas series de fuentes hemerográficas. ${ }^{2}$ Sin embargo, para fases anteriores todavía no han experimentado el desarrollo que el tema merece, en particular en el siglo XVIII en que la música se convirtió en un pasatiempo al alcance de la sociedad y los edificios para la música comenzaron a adquirir presencia pública. ${ }^{3}$ La investigación sobre la historia de la música en los espacios públicos cuenta con algunos exponentes notables relacionados con la musicología urbana y el paisaje sonoro ${ }^{4}$ en la sociedad del Antiguo Régimen. La experiencia auditiva de los habitantes de las ciudades se ha convertido en objeto de estudio de musicólogos como Alain Corbain e historiadores como Alberto Marcos Martín o María José del Río, y el ruido ha sido investigado como medio de comunicación por antropólogos como González Alcantud y etnógrafos como Miriam Germán-González y Arturo O. Santillán..$^{5}$ A su vez, hay estudios ligados a la historia de las bandas musicales en el siglo XIX, ${ }^{6}$ que construyen el puente entre música y vía pública. Aunque la literatura sobre la sociabilidad en las alamedas es

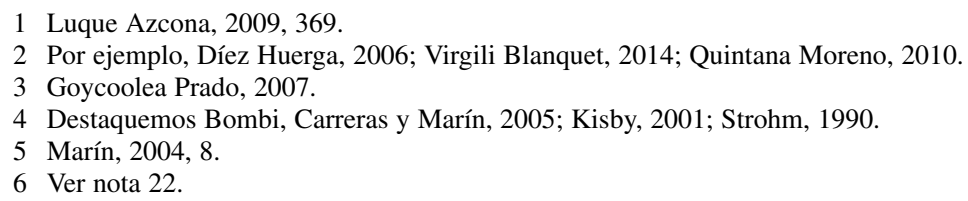


nutrida, ${ }^{7}$ la aportación de la música en particular no ha sido el objeto de estudio de ningún trabajo hasta el momento.

Este artículo aspira a determinar los orígenes y antecedentes de las prácticas musicales que tuvieron lugar en la sevillana alameda de Hércules en siglo XVIII y los fenómenos musicales con los que estaban emparentadas, para así explicar qué papel desempeñaron en la configuración de unos hábitos de sociabilidad urbana interestamental y en qué medida contribuyeron a la novedad y al éxito de los mismos. La indagación acerca del componente musical puede ayudar a discernir si prevalece la innovación o la continuidad con las formas de sociabilidad anteriores a la Ilustración. Ineludiblemente, el estudio de este espacio público además debe articularse con el de los demás ámbitos de la sociedad dieciochesca, con vistas a una comprensión global de la cultura musical urbana hispana. Lo cual a su vez contribuye a caracterizar a esta última con respecto a la de otras regiones europeas mejor conocidas y estudiadas.

Este trabajo se fundamenta en la alameda de Hércules como estudio de caso, debido a que se trata de un objeto de investigación que atesora cierto volumen de información coetánea. La abordamos mediante documentación narrativa, literaria y archivística confrontadas, haciendo hincapié en el siglo XVIII, que fue cuando actuó como ejemplo para la fundación de tantas otras, pero remontándonos a sus orígenes a su vez. Puesto que fue el modelo arquitectónico de las alamedas americanas (junto con la alameda del Prado de Valladolid ${ }^{8}$ y el paseo del Prado de Madrid como espejo de alamedas reformadas bajo Carlos III), ${ }^{9}$ es razonable pensar que también fuera su ejemplo en cuanto a hábitos sociales asignados. Al menos, eso es lo que da a entender la vaga información de que se dispone sobre ellos. Abordar el estudio de la música en las alamedas de Hispanoamérica sería un asunto cuyo tratamiento ocuparía varias decenas de artículos e incluso algunos libros. Por consiguiente, como primer paso profundizaremos en el caso sevillano, pues creemos que el conocimiento del ejemplo hispalense puede contribuir a un acercamiento a los casos hispanoamericanos con unas expectativas y una metodología adecuadas.

Abordaremos en primer lugar la descripción del paisaje musical que de la alameda trazan las fuentes contemporáneas; posteriormente documentaremos la realización material de esos servicios musicales. Esto

7 Luque Azcona, 2009; Morales Folguera, 1989; Page, 2007.

8 Durán Montero, 1985.

9 Luque Azcona, 2009, 371. 
conducirá a una reflexión sobre el sentido y los objetivos de la presencia de música en la alameda, en relación con otros contextos similares en la vida urbana. La valoración de la consecución de sus objetivos llevará a indagar sobre el impacto que producía en el auditorio, en íntima relación con el resto de experiencias musicales públicas y privadas que este tenía en el siglo XVIII. Finalmente, proyectaremos el fenómeno en el tiempo, remontándonos a sus orígenes para calibrar su éxito y las razones últimas de su existencia.

\section{¿Cómo era la música de alameda según las fuentes narrativas?}

Rara es la alameda que no cuenta con alguna referencia histórica que avale la presencia de la música en el siglo XVIII. Como ejemplo español, destaquemos la de Sevilla, de la que tenemos testimonios documentales, ${ }^{10}$ literarios ${ }^{11}$ y gráficos. ${ }^{12} \mathrm{~A}$ juzgar por las fuentes, la música fue un elemento íntimamente asociado a la alameda desde su inauguración a través de toda la Modernidad. Por añadidura, aunque se sabe poco en la mayor parte de los casos sobre la frecuencia, el repertorio y los integrantes, se tiene conocimiento de que en todas las ciudades hispanas existían conciertos públicos en espacios abiertos por parte de los músicos municipales, ya fueran trompetas o ministriles, que suelen coincidir en espacios ajardinados y propicios para el paseo. En Granada y en Zaragoza, por ejemplo, es sabido que tenían lugar en las tardes de verano en la ribera del río. ${ }^{13}$ En Fuenterrabía, sabemos que en 1785 se utilizaba como «una bellísima estancia tanto para el paseo y trato de la gente [...] como para los bailes públicos del tamboril», siendo escenario de manifestaciones de sociabilidad y de música no solo en el siglo XVIII sino también en el XIX. ${ }^{14}$ En Hispanoamérica, por ejemplo en la alameda de la Ciudad de México también se sabe que se tocaba música los días festivos..$^{15}$

10 Matute y Gaviria, 1997, 162.

11 Pintura que le da algún ayre al Paseo de la Alameda, British Library, Additional Manuscripts, 20.792 (21), f. 281-289. Mis agradecimientos a Manuel Francisco Fernández Chaves por haber localizado y compartido este documento.

12 En los azulejos del monasterio de la Encarnación de Osuna en 1780 aparece una representación de la vista de la alameda de Hércules de Sevilla en la que, sobre un estrado, tañen seis músicos. Apud. Méndez Rodríguez, 2007, 411.

13 Marín, 2004, 19.

14 Bosqued Lacambra, 2010, 9.

15 Gonzalbo Aizpuru, 2003, 602. 
¿A qué tipo de música nos referimos? Las descripciones mencionan instrumentos musicales, no siempre definidos, que a priori se utilizaban para interpretar composiciones polifónicas y estrictamente instrumentales. En la sevillana alameda de Hércules, en las fuentes originales se menciona «la variedad de sus tocatas de acordes, y varios instrumentos» durante el Lustro Real (1729-1733), ${ }^{16}$ «una numerosa orquesta» y «un coro de clarines» que daban la bienvenida al comienzo del paseo a los caballeros y damas en la velada de San Juan de $1795,{ }^{17}$ y «ministriles y chirimías» en las fiestas ordinarias de $1796 .{ }^{18}$ Un poema satírico manuscrito del último tercio del siglo XVIII, que Aguilar Piñal atribuye al sevillano clérigo Donato de Arenzana, ${ }^{19}$ luego de recrear el escenario de la alameda hispalense, se ve obligado a equilibrar este paisaje visual con un paisaje sonoro, dada la íntima vinculación de la música con este espacio desde su inauguración a través de toda la Modernidad. Le dedica no menos de cuatro estrofas al tema, pero no informa más que de la existencia de «sonoros acordes instrumentos»..$^{20}$

A su vez, es frecuente que los efectivos musicales se identifiquen como militares, lo cual constituye una primera manifestación del predicamento que las bandas gozaron en la vida pública del siglo XIX. ${ }^{21}$ En el siglo XVIII, la sociedad española se militariza en cierta medida y la música militar, antes tan desligada de la vida urbana, va a encontrar su espacio. ${ }^{22}$ Por ejemplo, el asistente de Sevilla en uno de sus primeros actos públicos acudió a la velada de San Juan en 1795 con un piquete militar con banda de música incluida para recorrer la alameda, que era la actividad para la que se construyó. ${ }^{23}$

A primera vista, esta diversidad que muestran las distintas fuentes podría resultar confusa. Quizá haya que considerar la naturaleza de los ambientes que fueron retratados: el paisaje sonoro de la alameda parece adaptarse a las circunstancias, como el del resto de la ciudad. Como se

16 Zúñiga, 1748, 183.

17 Matute y Gaviria, 1997, 162.

18 Ortiz de Zúñiga, 1988, IV, 71.

19 Aguilar Piñal, 1981, I, 356.

20 Pintura que le da algún ayre, $284 \mathrm{v}$.

21 Numerosos estudios avalan el importante papel que tuvieron las bandas en la vida musical urbana decimonónica, tanto en España como en Hispanoamérica. Por ejemplo, Navarrete Pellicer, 2001; Capdepón Verdú, 2011; López Cobas, 2008; Cabeza Rodríguez, 1991; Daza Palacios, 2010; Clares Clares, 2005; Astruells Moreno, 2003; Sánchez Huedo, 2008.

22 Gil Arráez, 2014.

23 Matute y Gaviria, 1997, 162. 
puede observar, el contexto de la visita real a Sevilla parece sugerir que los efectivos musicales estaban más diversificados que nunca («variados instrumentos»), y que en la festividad de San Juan (como ocasión extraordinaria) también sucedía (clarines y orquesta), mientras que en las ocasiones más ordinarias tan solo se mencionan los instrumentos típicos y tradicionales de una copla de ministriles (chirimías).

\section{¿Cómo se producía la música de alameda según las fuentes administrativas?}

Dada la vaguedad de las fuentes narrativas, no hay más remedio que dirigirse a los archivos, a la documentación administrativa, para determinar qué tipo de música es la que estuvo disponible en la alameda sevillana. ¿Cómo se producía aquella música? ¿Quién aportaba los recursos necesarios? ¿Quién la interpretaba y en qué condiciones? Todas estas preguntas afloran una vez que adoptamos una perspectiva más profunda que la descriptiva del ambiente, y sus respuestas conducirán a explicar la función que aquella música desempeñaba en dicho lugar. En el caso de Sevilla, los recursos musicales de la alameda procedían de las arcas públicas: el concejo municipal consignaba en la diputación de propios los gastos relativos a este espacio. Existía una diputación municipal de la alameda, compuesta por un regidor y un jurado del concejo, elegidos anualmente por urnas, ${ }^{24}$ una de cuyas funciones era cerciorarse de que los músicos municipales cumplían sus obligaciones en la alameda. Ya los contemporáneos tenían conciencia de ello, como demuestra Ortiz de Zúñiga corregido y editado por Espinosa y Cárcel en 1796: «a veces se tienen otros públicos festejos, a veces alegría de músicas, y de ordinario en las fiestas, ministriles y chirimías, pagados de lo público». ${ }^{25}$

La primera libranza a los ministriles municipales por su trabajo en la alameda de Hércules tuvo lugar en $1585 .{ }^{26}$ No tocaban todas las noches del verano, tan solo algunas, las correspondientes a los días festivos y los domingos. A mediados del siglo XVII la temporada de verano sumaba 17 actuaciones de los ministriles (desde el 24 de junio hasta el 25 de agosto). ${ }^{27}$

24 Ortiz de Zúñiga, 1988, IV, 71.

25 Apud Márquez Redondo, 2010, t. 2, 690.

26 AMS, Sec. XV, Mayordomazgo, Libro manual de caja 5, 15 de octubre de 1585.

27 AMS, Sec. II, Contaduría, Acuerdos para librar, t. 26, 1, doc. 39. 
Así rezaba en la lista de obligaciones que comprendía el contrato de trabajo de los ministriles municipales, que se fue renovando sistemáticamente:

Que sean obligados a servir quatro meses del verano junio, jullio, agosto y setiembre en el alameda todos los días de fiesta una hora antes de la oración y por cada bes que faltaren se les quiten dos ducados de su salario y para esto se les dé casa cómoda donde sirban la quel procurador mayor les señalare.

En estas fechas, todavía no existía una plataforma y los ministriles tocaban desde la azotea o el balcón de una casa. El papel que los ministriles desempeñaban en la alameda se consideraba fundamental en el cumplimiento de su trabajo, puesto que se le daba preeminencia a la hora de evaluarlo, encargándose siempre a algún miembro del concejo que obtuviera informes acerca de su cumplimiento:

Yten que para librarles el salario, al fin del año traigan del procurador mayor y del diputado del matadero y del del alameda cómo an servido y las faltas que an fecho porque al respecto de lo que está declarado tanto menos les libren de sus salarios o les paguen por entero si ovieren servido bien. ${ }^{28}$

En el siglo XVIII los trompeteros municipales, que hasta entonces no habían ejercido la labor de amenizar la atmósfera de la alameda, comenzaron a asumirla además de sus habituales obligaciones cuando su instrumento hubo evolucionado hasta la tipología del clarín, el pariente más agudo de la trompeta, con origen en el mundo militar. Tenía un diapasón más elevado que el de la trompeta y su diámetro se ensanchaba gradualmente hasta el pabellón. Su evolución desembocó en la corneta de llaves actual. En 1679 aparece el primer clarinero en las nóminas de la Caballeriza Real, ${ }^{29}$ y en Sevilla en $1653,{ }^{30}$ y en el siglo XVIII habrá sustituido a la trompeta en todos los ámbitos. A comienzos del siglo XVIII, su sueldo era de 1.650 reales anuales, pero a partir de 1768 ascendió a 1.950, además de las propinas que le cabían en ceremonias festivas como la del Corpus, de 50 reales. ${ }^{31}$

En 1716, eran dos músicos los que tocaban el clarín en la alameda de Hércules, recibiendo 600 reales de salario por hacerlo todas las noches del verano. A los que se les sumaba un número indeterminado de clarineros adicionales solo en las noches de fiesta, retribuidos con 109 reales. ${ }^{32}$ Puesto

28 Archivo Histórico Provincial de Sevilla (AHPdS), Protocolos Notariales, oficio 22, leg. 15074, libro 6. ${ }^{\circ}$ de 1604, 21 de septiembre de 1593, s/f.

29 Kenyon de Pascual, 1995; Smithers, 1933.

30 AMS, Sec. XV, Mayordomazgo, tomo 31, lib. H-3206, 5 de diciembre de 1653.

31 Márquez Redondo, 2010, t. 1, 380.

32 AMS, Sec. XV, Mayordomazgo, Libro manual de caja 39, 5 de abril de 1717. 
que recibían 15 reales por noche, sale un cociente de 40 actuaciones para 1716, de las cuales 7 eran festivas. En 1718 subió a 1.263, sin duda inflado por la contratación de ministriles (los cuales siempre gozaron de mayor status en virtud de su cualificación como músicos) además de los clarineros para las ocasiones festivas..$^{33}$

De hecho, en 1724 realizan su primera aparición en la alameda los instrumentos de cuerda frotada (violines) junto con los clarineros, y el presupuesto (1.112 reales) confirma la correlación entre duplicación del gasto e incorporación de cualificados músicos cultos. ${ }^{34}$ Los violinistas, por cierto, ya tocaban en la capilla catedralicia hispalense desde el siglo XVII y se habían incorporado a su plantilla en 1732 mediante la creación de seis plazas supernumerarias. ${ }^{35}$

En la mayoría de los años, los gastos de la alameda no aparecen desglosados en la documentación, por lo que ignoramos cuánto se pagó a los músicos aunque se menciona la presencia de «ynstrumentos de cuerda y clarines que asistieron las noches de las temporadas del verano». ${ }^{36}$ Aquí presentamos los años en los que las fuentes permiten determinarlo:

\begin{tabular}{|c|c|c|}
\hline & $\begin{array}{l}\text { Gasto anual en músicos de la } \\
\text { alameda (en reales de vellón) }\end{array}$ & $\begin{array}{l}\text { Porcentaje con respecto al gasto } \\
\text { total anual en la alameda }\end{array}$ \\
\hline 1716 & 709 & $22 \%$ \\
\hline $1717^{37}$ & 638 & $22 \%$ \\
\hline 1718 & 1.263 & $30 \%$ \\
\hline $1719^{38}$ & 660 & $19 \%$ \\
\hline $1720^{39}$ & 660 & $13 \%$ \\
\hline $1723^{40}$ & 1.112 & $6 \%$ \\
\hline 1729 & 1.650 & $20 \%$ \\
\hline 1731 & 1.770 & $47 \%$ \\
\hline $1736^{41}$ & 1.254 & $20 \%$ \\
\hline $1737^{42}$ & 1.650 & $38 \%$ \\
\hline \multicolumn{3}{|c|}{33 Ibidem, 25 de enero de 1719.} \\
\hline \multicolumn{3}{|c|}{34 Ibidem, 3 de abril de 1724 . } \\
\hline \multicolumn{3}{|c|}{35 Suárez Martos, 2007, I, 210; Isusi Fagoaga, 2003, I, 107.} \\
\hline \multicolumn{3}{|c|}{36 AMS, Sec. XV, Mayordomazgo, Libro manual de caja 39, 2 de abril de 1728.} \\
\hline \multicolumn{3}{|c|}{37 Ibidem, 10 de marzo de 1718 . } \\
\hline \multicolumn{3}{|c|}{38 Ibidem, 12 de junio de 1720 . } \\
\hline \multicolumn{3}{|c|}{39 Ibidem, 8 de marzo de 1721 . } \\
\hline \multicolumn{3}{|c|}{40 Ibidem, 3 de abril de 1724.} \\
\hline \multicolumn{3}{|c|}{41 AMS, Sec. XV, Mayordomazgo, Libro manual } \\
\hline
\end{tabular}


Queda de manifiesto que los poderes municipales invierten un presupuesto en la música de la alameda, sin que esta esté contemplada o incluida en las obligaciones habituales de los músicos que el concejo tiene en nómina. Tanto si tocaban los músicos municipales como otros profesionales contratados expresamente para la ocasión, el cabildo debía realizar libranzas. El coste en música suponía alrededor de un $20 \%$ del presupuesto anual gastado en la alameda en condiciones normales, lo cual denota el porcentaje de importancia que se concedía al paisaje sonoro respecto al visual. En determinadas fechas, la magnanimidad demostrada en música se vio ampliamente superada por la inversión total y en otros momentos sucedió al revés. Durante el Lustro Real, la dotación musical de la alameda se amplió espectacularmente: en 1729 se pagaron los acostumbrados 660 reales solo a los clarineros, mientras que los «músicos» propiamente dichos recibieron $990 .{ }^{43}$ Esto es, el gasto en la música de la alameda igualó por primera vez al que suponía la música municipal de todo el año: la función recreativa de la música se puso a la altura de su función heráldica. En 1731 incluso se incrementaron ambas partidas musicales de la alameda: 1.050 para los violinistas y 720 para los clarineros ${ }^{44}$ Es natural que se introdujeran los violinistas para agasajar a un rey que encontraba en la música de cámara y operística consuelo para sus desequilibrios psicológicos. ${ }^{45}$

Esta composición mixta de la música se mantuvo después de la partida de la corte real. Mientras los clarineros continuaron cobrando 660 reales indefectiblemente, los violinistas fluctuaron entre 594 y 990 . En 1747 los dos clarineros y los tres músicos seguían cobrando lo mismo por su trabajo estival en la alameda. ${ }^{46}$ Sabemos que en 1759 el teniente de alguacil se opuso a continuar subvencionando las actuaciones musicales en la alameda, argumentando que era un lastre para los bienes de propios del concejo, que era una costumbre exclusivamente sevillana, que los músicos no siempre cumplían con su obligación y que en cualquier caso el público menos cultivado no apreciaba esta dádiva artística. El reglamento de 1768 suprimió la libranza de la música de la alameda por no considerarla de beneficio público. ${ }^{47}$ Sin embargo, tenemos testimonios narrativos, ya citados, que

43 Ibidem, 9 de mayo de 1730.

44 Ibidem, 17 de marzo de 1732.

45 El paisaje completo de las actividades musicales que tuvieron lugar en Sevilla durante la visita real está recogido en Morales, 2010; Gembero Ustarroz, 2010; Isusi Fagoaga, 2004.

46 AMS, Sec. XV, Mayordomazgo, Libro manual de caja 41, 9 y 28 de septiembre de 1747.

47 Márquez Redondo, 2010, t. 2, 903. 
mencionan a la música de la alameda en la última década del siglo en el contexto de festivo, por lo que la tradición no se perdió enteramente.

¿En qué condiciones tocaban estos músicos, de una u otra especie? Las fuentes hablan de su estatismo sobre atalayas o pedestales. La primera noticia en la documentación municipal sevillana en 1619 se refiere a «una torrecilla en el alameda desta çiudad, para tocar los veranos los ministriles», ${ }^{48}$ a la que en 1621 se añadieron celosías. ${ }^{49}$ En otras ciudades nos consta que se ubicaron similares instalaciones en fechas igualmente tempranas: el templete llamado «Casa de las Chirimías» de Valladolid fue construido en 1601 en el prado de la Magdalena ${ }^{50}$ en el paseo del Prado de Madrid también había una torrecilla mirador para los músicos desde $1612,,^{51}$ activos en los meses de verano, y también para servir refrescos de aloja, antes de ser demolida en el siglo XVIII por Ventura Rodríguez, ${ }^{52}$ y en 1609 se levantó la «Casa de las Chirimías» del paseo de los Tristes de Granada, que era un mirador sobre el río Darro. ${ }^{53}$

Lorenzo Baptista de Zúñiga se refiere a cuatro palquetos durante el Lustro Real, ${ }^{54}$ lo cual ilustra sobre la cantidad y dispersión de los efectivos musicales, que como ya sabemos tuvieron que multiplicarse. El poema anónimo dieciochesco al que ya hemos aludido, más tardío, menciona un tablado de madera, aunque más tarde bromea con la idea de que fuese de cal y canto. El autor, con su lenguaje tan lírico como satírico, la califica de «arca». A la sombra de un árbol, esta estructura inspira conmiseración al poeta por su incomodidad, llegando a considerar que para los músicos suponía una penitencia. ${ }^{55}$ Las fuentes municipales la denominaron «cajón» cuando se pagó una de sus construcciones en 1761 al maestro de carpintería ${ }^{56}$ Ya en 1795, Matute y Gaviria se refiere a un terrado de fábrica como plataforma para la orquesta, ${ }^{57}$ lo cual sugiere una tendencia a la estabilidad. En los paseos públicos que surgen en estas fechas también se distribuyen elementos decorativos e infraestructuras para espectáculos (quioscos y

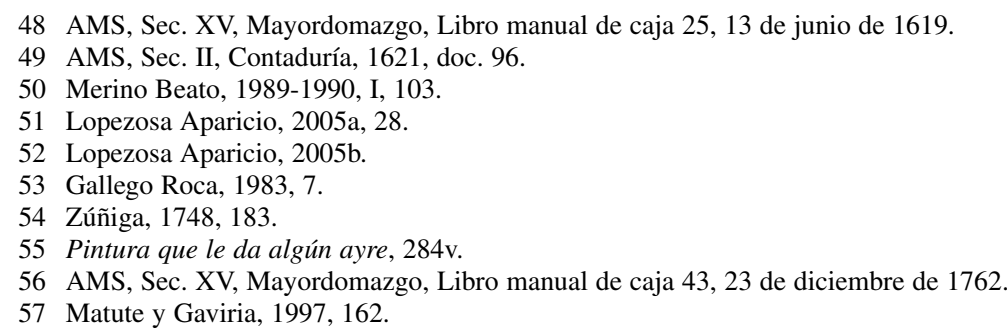


templetes de música), tanto en España ${ }^{58}$ como en Hispanoamérica. ${ }^{59}$ En el salón del Prado de Madrid la fuente de Apolo, dios de las artes y la música, dominaba el aparato iconográfico y sobre el pórtico en 1775 Ventura Rodríguez dispuso un terrado para los músicos. ${ }^{60}$ Comparemos el fenómeno con el del mobiliario y la decoración de las plazas mayores (entre ellos el quiosco de música) que en la Edad Moderna fue desmontable, efímero y adaptable, mientras que en la Edad Contemporánea se sedentarizó porque la plaza mayor dejó de ser un espacio polivalente: muchas de las funciones que había desempeñado se trasladaron a instalaciones específicas permanentes. ${ }^{61}$ En cualquier caso, interesa destacar que los músicos siempre tañeron desde la altura por razones de acústica, puesto que el espacio era demasiado grande y demasiado bullicioso, y también por motivos de representación: al cabildo civil le convenía hacer exhibición de ellos y de sus uniformes municipales, no solo auditiva sino también visual. ${ }^{62}$

\section{¿Por qué se producía la música de alameda?}

De hecho, la presencia de los músicos en las veladas más concurridas de la alameda tiene como fin último una suerte de glorificación del concejo municipal como artífice de aquel acabado parque del bienestar. Puesto que la música supone el paradigma del derroche por lo que tiene de efíme$\mathrm{ra}$, que el concejo asumiera aquel dispendio confirmaba su liberalidad y creaba una ilusión de salud de sus arcas en la opinión pública. La magnificencia estética siempre contribuyó al efecto de suspensión y maravilla que perseguía la propaganda de los poderes municipales.

Desde el Renacimiento persistía una conciencia de que a los poderes correspondía cierta responsabilidad en el entretenimiento y recreo de la población, y la Ilustración reeditó esta preocupación propiciando la urbanización de las ciudades y la organización de bailes públicos ${ }^{63}$ La alameda de Hércules era un espacio de esparcimiento aun antes de ser desecada, pues allí tenían lugar corridas de toros, cañas, justas, torneos y otros

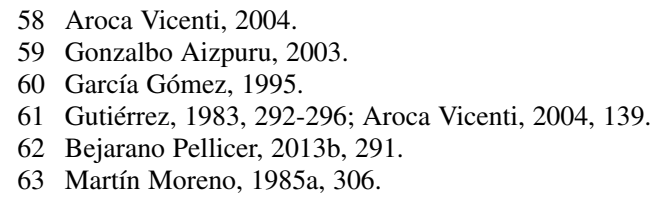


deportes nobiliarios. Al ser urbanizada, se convirtió en un espacio de representación de la sociedad urbana. ${ }^{64}$ Los veinticuatros que en el siglo XVIII defendieron la continuidad y utilidad social de la música de la alameda, como por ejemplo Ignacio Retana, quien argumentó que la ciudad estaba escasa de diversiones y que la alameda era un espacio de «desahogo para el público por lo demasiado que fatiga el estío en este país» ${ }^{65}$ De hecho, existen fuentes literarias que atestiguan esta vinculación de los paseos en coche, el verano y la música con la alameda: en la comedia La Alameda de Sevilla de Cristóbal de Monroy (primera mitad del siglo XVII), don Diego atestigua su función social al indicarle a su hermana «Doña Leonor, bien podéis ir esta noche a la alameda en el coche pues haze tanto calor», adonde ella lleva consigo un arpa para cantar. Nótese que la misma obra revela que la alameda de Hércules en el siglo XVII se podía considerar una gloria sevillana que los visitantes no podían dejar de visitar. Un joven sevillano muestra la ciudad a su primo cortesano, que está de visita, y después de llevarlo a la catedral «cuya fábrica gallarda no tiene igual», lo conduce a la alameda. ${ }^{66}$ Arana de Valflora en su Compendio histórico descriptivo de la ciudad de Sevilla también salía en defensa moral de los paseos como esparcimiento y como desahogo de tensiones. ${ }^{67}$

La música de la alameda de Hércules no fue la única a la que el concejo municipal permitió el acceso a la población urbana en el espacio público. En el contexto de las fiestas públicas, además de la música litúrgica que tenía lugar en las ceremonias religiosas, en las fiestas y en el curso de las procesiones, el concejo solía instalar a sus ministriles en las arquerías de su edificio de la plaza de San Francisco o en tablados al aire libre, para que contribuyeran a crear una continua atmósfera de regocijo y solemnidad, muy especialmente por las noches. A veces se refería a algún tablado que se levantaba en la plaza para su comodidad y adecuada proyección; en otras ocasiones los ministriles se situaban en los balcones o corredores de la loggia del propio ayuntamiento. Los músicos podían ser divididos en varias copias para distribuirlos por varios puntos de la plaza, sobre tablados, con la intención de crear efectos estereofónicos. Por citar un ejemplo contemporáneo, en las fiestas por la proclamación de Carlos IV en 1789:

64 Fernández Chaves, 2012.

65 Márquez Redondo, 2, 2010, 903.

66 Monroy y Silva, s/f, 4-5.

67 Fernández Chaves, 2007; Arana de Valflora, 2003, 94. 
La función y la alegría duraron hasta las siete de la mañana, divirtiendo también al Público toda esta noche y las tres anteriores hasta las once las dos Orquestras de Música colocadas en la fachada de dichas Casas Capitulares al pie de los Reales Retratos. ${ }^{68}$

El cabildo municipal ofrecía a los ciudadanos anónimos el placer de escuchar música profana instrumental de la mejor calidad, privilegio que en el tiempo ordinario estaba reservado a quien podía pagárselo. De hecho, las clases altas disfrutaban de sus propias fiestas en ámbitos privados. Hay quien apunta que estos fueron los primeros conciertos propiamente dichos de la Historia de Occidente, y que a partir de aquel momento la música instrumental comenzó a valorarse no como un mero oficio, sino como un arte. ${ }^{69}$ También se puede interpretar como una sutil forma, sin recurrir a la imposición, de apropiarse del espacio urbano mediante sugerencia. ${ }^{70}$

Yendo más allá, la iniciativa complementaria a las mencionadas fue ofrecer música recreativa a disposición del público sin necesidad de que mediara un motivo festivo. Los conciertos gratuitos en la alameda en las noches de verano alentaron su centralidad para la sociabilidad sevillana y redondearon la impresión paradisíaca que ella inspiraba. Los jardines pretendían recrear la Arcadia, un mundo pasado perdido idílico, y el mundo campesino en plena ciudad. Y en el imaginario colectivo, en el paisaje pastoril la música tenía un papel. ${ }^{71}$ Quizá en todo ello pueda adivinarse cierta competencia con el cabildo eclesiástico sevillano, a la sombra del cual estuvo siempre el municipal en cuestiones musicales. Si bajo las bóvedas de la catedral se desarrollaron siestas y otros espectáculos musicales extralitúrgicos $^{72}$ con frecuencia, el concejo sacó sus recursos musicales al aire libre y los situó en el escenario que encarnaba el esplendor del urbanismo renacentista. No fue hasta el espíritu reformista ilustrado de 1768 cuando el concejo municipal puso en duda la utilidad social de la música en la alameda.

La mentalidad renacentista imaginó la alameda como un jardín edénico en el que se concitaran todos los placeres sensoriales que ayudaran a la ciudadanía a abstraerse de las incomodidades de una populosa urbe. Como dice Fermín Arana de Valflora también en 1789,

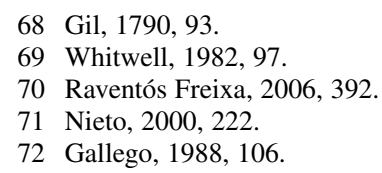


Son los paseos a un tiempo mismo ornato de los pueblos, y honesto esparcimiento de sus moradores. La vida humana cercada de indispensables molestias, necesita algún inocente desahogo, que suavice sus frecuentes desabrimientos. ${ }^{73}$

El íntimo jardín medieval se convirtió en la Modernidad en un salón señorial para el encuentro y disfrute de saberes y placeres refinados. ${ }^{74}$ Este refugio de naturaleza antropizada en el seno de la ciudad aspiraba a constituir un jardín paradisíaco. Al concepto de jardín no le es extraña la música, comenzando por los cantos de las aves. La música instrumental supone un paso más en la dirección de la estilización de la naturaleza, puesto que no solo imita sino que también mejora lo propuesto por el paisaje. La innegable composición matemática de la música y sus capacidades sosegadoras del espíritu estaban en consonancia con el efecto armónico al que el esteta del Renacimiento aspiraba. ${ }^{75}$ De hecho, sabemos que al menos en el Lustro Real la música tocaba «las noches que duró el riego», ${ }^{76}$ lo cual sugiere que formaba parte de un espectáculo de fuentes y sonido. En el siglo XVIII, la presencia de la corte en Sevilla entre 1729 y 1733 impulsó la urbanización de los jardines y su uso como marco para fiestas y música, al mismo tiempo que familiarizó a la nobleza hispalense con las costumbres musicales de la corte borbónica, sus bailes y actividades musicales escénicas. ${ }^{77} \mathrm{El}$ interés que las reales personas tenían en los espacios ajardinados y que transmitieron a la población fue el de utilizarlos como recreo en las noches de luna, sin que pudieran faltar «la prevención de Músicos y variedad de instrumentos». ${ }^{78}$ Los infantes frecuentaron el paseo de la alameda. ${ }^{79}$

Se desconoce el repertorio que interpretaban los músicos de la alameda. Todo lo que las fuentes permiten colegir es que se trataba indefectiblemente de música instrumental. Sabiendo que en períodos posteriores serán las bandas militares y municipales las que tomen el relevo, podemos pensar que la música que los clarineros, ministriles y violinistas concejiles de la Edad Moderna tuvo el mismo carácter popular que los conciertos públicos decimonónicos. No en vano las bandas adaptaron el repertorio

73 Arana de Valflora, 2003, 94.

74 Añón y Sancho, 1998, 45-72.

75 Aracil, 1998.

76 AMS, Sec. XV, Mayordomazgo, Libro manual de caja 40, 17 de marzo de 1732.

77 Gutiérrez Cordero, 2008, 40.

78 AMS, Sec. XIII, Papeles Importantes, tomo 7, «Grandezas con que la ínclita, famosa, MN i ML ciudad de Sevilla obstentó su expesial júbilo en la venida a ella el año de MDCCXXIX la Magestad de su Rey y Señor Don Phelipe V...», f. 395. León, 1990; Morales, 2010.

79 Márquez Redondo, 1994, 96. 
coreográfico de las orquestas de salón y lo sacaron a las calles, convirtiéndolo en música popular al formar parte de la experiencia urbana de todos. El desarrollo de la música popular entendida como género comercial, urbano, asequible y de fácil acceso para el consumo de todos los públicos, en oposición a la música artística o culta que comenzaba a canonizarse, tuvo sus orígenes en la creación de la sociedad burguesa en el siglo XVIII en Europa y América, ${ }^{80}$ por lo que parece plausible pensar que las alamedas pudieran contribuir a este proceso, en tanto que espacios privilegiados para la configuración de una experiencia musical común e interclasista.

\section{¿Cuál fue la recepción de la música de alameda?}

Comprendemos las razones e intenciones por las que la música fue introducida en las alamedas, pero resta averiguar si esta cumplió su objetivo. ¿Qué efecto producía en los viandantes? ¿Qué actitud demostraba el público ante estas manifestaciones auditivas? Estas preguntas, que entroncan con la historia de la recepción musical, tan en boga, no tienen fácil respuesta porque para la Edad Moderna faltan las fuentes hemerográficas que hacen las delicias de los investigadores sobre la Edad Contemporánea. ${ }^{81} \mathrm{De}$ la opinión pública ofrecen un pálido reflejo las citas de los cronistas locales, que no se pueden considerar exactamente representativas del común, y menos considerando que sus testimonios no se refieren siempre a su propia época. La mayoría de las menciones a la música en fuentes originales es de carácter elogioso o neutro, ponderando las cualidades estéticas de esta música con un vocabulario manido, poco informativo, propio de la literatura corográfica de exaltación de las ciudades. Por ejemplo, se destaca «la variedad de sus tocatas de acordes, y varios instrumentos». 82

Si existe un testimonio al que podamos atribuir un mínimo de frescura, es el poema anónimo del siglo XVIII que venimos citando sobre la alameda de Hércules. Aunque ensalzará el ambiente musical con adjetivos e imágenes poéticas muy entroncadas en el lenguaje literario de la Modernidad, en cambio también contiene notas satíricas que aportan ciertas pistas. Es habitual en las fuentes narrativas de los siglos XVI al XVIII

80 Middleton, 2001.

81 Por citar algún ejemplo, mencionemos dos españoles y uno americano: Salinas, 2011; Gimeno Arlanzón, 2010; Quintana Moreno, 2010.

82 Zúñiga, 1748, 183. 
encontrar epítetos dedicados a la música y los instrumentos como los que aparecen en este poema: dulciloquio, melifluo, suave, sonoro, acorde, grave, dulce, tierno. Asimismo, el autor de la composición que tratamos escapó al compromiso de la mera descripción afirmando que la destreza de los músicos de la alameda sevillana sobrepasaba a las figuras musicales más sobresalientes del repertorio mitológico: Apolo, Orfeo y Anfión. ${ }^{83}$ Sin perjuicio de todo lo cual, que encaja con coherencia en la tradición literaria sevillana de la época, cabe sospechar que el descarado poeta estuviera empleando la ironía para burlarse de la calidad del espectáculo musical. Especialmente significativas resultan las afirmaciones de que de este aprendían a cantar las aves nocturnas (citadas las más escandalosas de ellas: tordos, cernícalos y grajos), o que los músicos sevillanos podrían irse a tocar a los infiernos (para reemplazar a Orfeo, entiéndase).

Y si los literatos se burlaban de los músicos con la pluma, otros sectores menos refinados de la sociedad hispalense del siglo XVIII encontraban formas más sensibles de manifestar el mismo desprecio: argumenta el teniente de alguacil mayor Alonso Venegas en 1759 que «los tres músicos que se ponían en el cajón de la alameda eran el blanco de los chuscos y muchachos para tirar piedras y cuantas porquerías había en ella y hacer burla» ${ }^{84}$ Así se entiende por qué al poeta se le antoja que permanecer sobre aquel cajón era una penitencia.

Esto entronca con una corriente dieciochesca de ridiculización de los músicos que asoma en las mascaradas estudiantiles del fasto público, por ejemplo la que se hizo en el colegio de Santo Tomás de Sevilla en 1742 en honor al nuevo arzobispo Luis Jaime de Borbón, y también la de 1789 por la proclamación de Carlos IV, si bien se limitaban a desacreditar la caduca institución de la capilla musical eclesiástica. Entre las figuras jocosas de la primera iba una capilla de música burlesca, compuesta de varios ministriles, músicos cantores, dos seises y su maestro de capilla. Cada personaje llevaba un mote en cuatro versos que definía el vicio tópico que se le aplicaba. ${ }^{85}$ En la segunda de las máscaras citadas, se ridiculizaba al maestro de capilla, al flauta travesera, al chirimía, al violinista, al bajonista. ${ }^{86}$ En este contexto, tampoco es infrecuente la ridiculización de la figura de los músicos como ignorantes: «Uno de la Capilla llevaba baxón, otro viguela, otro

83 Pintura que le da algún ayre, 284-285.

84 Márquez Redondo, 2, 2010, 903.

85 Aplauso real, 1742, 32-33.

86 El triunfo de la sabiduría, 17-22. 
los papeles de Música con su solfa, todos ridículamente vestidos en borricos» ${ }^{87}$ En los tratados teórico-musicales españoles del siglo XVIII se hacen referencias al comportamiento de los músicos en público para impedir el deterioro de su imagen profesional. Las Sociedades Económicas de Amigos del País publicaron documentos en que insistían en que en la música contemporánea se contenían tantas bondades como en la antigua, sin duda con ánimo de combatir la desvalorización en que había caído la composición musical del siglo XVIII. Acaba con un dodecálogo que deberían seguir los músicos, y que ilustra acerca de sus costumbres groseras. ${ }^{88}$

Testimonios como estos hacen pensar que ni los músicos ni su música gozaban de una buena reputación en la opinión pública, o al menos la de aquellas instituciones tradicionales (los cabildos municipal y eclesiástico) que en el siglo XVI habían constituido el orgullo de la ciudad manifestado en las crónicas, pero que ya no eran valoradas. De hecho, existía en el propio siglo XVIII (impresión heredada por la historiografía hasta fechas recientes) una conciencia de decadencia de la música barroca española por contaminación de aportes italianizantes de carácter comercial, añorando los tiempos renacentistas en que España y Sevilla se habían situado en la vanguardia de la creación musical polifónica. Puede documentarse en los textos de los pensadores más representativos, como Antonio Eximeno, el padre Feijóo en sus primeros tiempos, el viajero Antonio Ponz, el compositor Francisco Valls ${ }^{89}$ o el dramaturgo Leandro Fernández de Moratín. ${ }^{90}$

En cualquier caso, las referencias de los cronistas a la música de la alameda nunca mencionan cómo interaccionaba el público con ella. Lo que sabemos positivamente era que a la alameda los ciudadanos acudían a pasear, preferentemente en carruaje. La actividad propia de este espacio era el paseo, y no parece que lo fuera la escucha atenta de un concierto: «frequentado de innumerables coches», lo describe Ortiz de Zúñiga. ${ }^{91}$ Cuando a fines del siglo XVI la moda de desplazarse en coche, venida de Italia, provocó atascos y accidentes en las angostas calles, el concejo sevillano tuvo que orientar su plan de urbanismo a la adaptación a los vehículos de ruedas, convirtiéndose la alameda de Hércules en el lugar favorito de paseo. ${ }^{92}$

\footnotetext{
87 Ortiz de Sandoval, 1707, 128.

88 Siemens Hernández, 1985, 135.

89 Gallego, 1988, 43; Alén, 2002.

90 Lolo Herranz, 2008.

91 Ortiz de Zúñiga, 1988, IV, 71.

92 Idem.
} 
Esta actividad no haría más que desarrollarse en el siglo XVIII, pues no por nada el gremio de fabricación de coches, como una especialidad de carpintería, se constituyó en Sevilla en 1707. ${ }^{33}$ Lamentablemente, las actividades de pasear en coche y gozar la música no parecen demasiado compatibles, debido al estruendo que provocaban las ruedas sobre la pavimentación de ladrillo o empedrado de la vía pública, ${ }^{94}$ sistemáticamente destruida por el tráfico. ${ }^{95}$

\section{¿Cuál era el contexto urbano de la música de alameda?}

En cualquier caso, la música de las alamedas no puede estudiarse como un fenómeno aislado del ambiente musical, del paisaje sonoro de las ciudades. Es necesario ponerla en relación con el conjunto de oportunidades que se le ofrecía a la población para escuchar música, muy particularmente en espacios públicos de libre acceso. ¿Con qué otras atracciones musicales tenían que competir estos eventos? ¿Los sevillanos estaban habituados a asistir a conciertos públicos? ¿Qué nivel de cultura musical se les puede atribuir? Es indispensable reconstruir la experiencia musical del público para valorar correctamente el impacto de la música de alameda.

En el siglo XVIII el consumo de música, tanto para oír como para interpretar, experimentó un desarrollo sin precedentes. Las clases medias en expansión comenzaron a demandar actividades comercializadas de ocio, formación musical, medios para practicarla (instrumentos y partituras domésticos $)^{96}$ y oportunidades de acceder a la audición bajo la forma de conciertos públicos, y los músicos empezaron a trabajar para un cliente anónimo ${ }^{97}$ En España, el fenómeno estuvo lejos de alcanzar las cotas de Inglaterra, Norteamérica o Centroeuropa, aunque también se perciba notable progreso en esos aspectos, ${ }^{98}$ así como en Hispanoamérica, ${ }^{99}$ si bien la música vocal (religiosa y teatral) tenía mucha más demanda que la

93 Recio Mir, 2005 y 2009; Roche, 2000.

94 Sabemos que la alameda estuvo parcialmente pavimentada desde 1574. Albardonedo Freire, 2002,348 y 352 .

95 Carmona García, 2000, 59-63.

96 El estilo italiano se difundió por el continente europeo, creando una estética internacional, gracias a la imprenta. Rasch, 2012.

97 Middleton, 2001.

98 Marín, 2014.

99 Waisman, 2014. 
instrumental. ${ }^{100}$ La Ilustración y el Enciclopedismo trajeron la inclusión de la música en los espacios semipúblicos y semiprivados que constituyeron las tertulias, saraos y salones a la francesa, en los que se tocaba el clave o la guitarra y se bailaba. El auge de la guitarra moderna es un fenómeno significativo de la segunda mitad del siglo XVIII. ${ }^{101}$ Los tratados de aprendizaje musical autodidacta dirigidos a diletantes y las academias de música se hicieron populares en dicha cronología. ${ }^{102}$ La educación musical se extendió particularmente entre las mujeres por convención social. ${ }^{103}$

En Sevilla todavía no existen estudios sobre la alfabetización musical, la posesión de instrumentos musicales o la práctica privada. En cambio, conocemos las actividades musicales que se llevaban a cabo de forma cotidiana en espacios públicos. El común tenía acceso a la audición de música de cierta elaboración en ámbito eclesiástico, en los teatros y en los ocasionales bailes de sociedad.

En la iglesia los sevillanos podían ser testigos de las intervenciones de las capillas musicales en las ceremonias del año litúrgico, con mayor despliegue cuanta más solemnidad se atribuyera a una determinada festividad. Ya a principios del siglo XVII, el padre Juan de Mariana se lamentaba de que los feligreses acudían a la iglesia como a un espectáculo: «y se mire que por el pueblo por cuya causa se reciben estas cosas no se acostumbre a ir al templo de la manera que a los espectáculos, juegos y otras fiestas profanas». ${ }^{104}$ En el siglo XVIII, sobre el papel emblemático que correspondió anteriormente a la capilla catedralicia sevillana proyectan su sombra nuevas capillas parroquiales en auge: la de la colegial de San Salvador, la de Santa Ana, la de San Pedro, la de la Magdalena, la de San Miguel etc. ${ }^{105}$ Las actividades de estas capillas no solo tenían lugar en sus sedes, sino que podían ser contratadas por cualquier corporación o particular con la mediación de un festero para un servicio concreto, en competencia con agrupaciones autónomas de músicos, de forma que extendían sus redes clientelares sobre la estructura institucional urbana, y la interpretación de música se realizaba tanto en espacios sacros como en la vía pública mediante procesiones. ${ }^{106}$ De hecho, los mismos ministriles que tocaban en la alameda para

100 Presas, 2012.

101 Suárez-Pajares, 2000.

102 Martín Moreno, 1985a, 293-294.

103 Martín Gaite, 1972.

104 Mariana, 2004, 155.

105 Bejarano Pellicer, 2013a.

106 Isusi Fagoaga, 2003, I, 246-291 y 305-324. 
el concejo solían pertenecer a la capilla catedralicia y hacer actuaciones en otras sedes eclesiásticas, lo cual refuerza la hipótesis de la interpenetración de repertorios.

El repertorio eclesiástico se nutría de música vocal coral en latín o en castellano con acompañamiento instrumental. Los estilos musicales que caracterizaban a las capillas eran muy diversos, combinando la textura polifónica y policoral de estilo contrarreformista con las cantatas de estructura napolitana y texto español, las formas concertantes venecianas, las arias y recitativos, el nuevo estilo galante inspirado en la música profana y el canto llano medieval. ${ }^{107}$ Esta convivencia entre tradición y modernidad en estilo y repertorio se manifestaba en misas, motetes, lamentaciones, oratorios y villancicos. Incluso en el repertorio organístico convivían el tiento y el verso con los géneros modernos como la tocata y la sonata. ${ }^{108}$ Naturalmente, también existían ocasiones puntuales en que la música popular y la culta se interpenetraban en la iglesia, como es el caso de los villancicos de los maitines de Navidad, semilitúrgicos y semiseculares, en lengua vernácula, que atraían a las masas gracias a su carácter local y su incorporación de temas populares prestados. ${ }^{109}$

A su vez, en la iglesia los feligreses tenían la oportunidad de gozar de conciertos públicos bajo la forma de siestas, la hora canónica en la que tenía lugar el protagonismo de la música instrumental sin las restricciones temporales típicas de la liturgia. A la hora sexta (desde las dos hasta las tres aproximadamente), creadas para atraer a los fieles y honrar al Santísimo Sacramento expuesto en adoración, estas manifestaciones acabaron extendiéndose en el horario y en el calendario. ${ }^{110}$ Esta tendencia a la secularización de la música en las catedrales, originada por las siestas, alcanza su culminación en el Siglo de las Luces con sonatas, tocatas y sinfonías. ${ }^{111}$

La música camerística fue democratizándose a lo largo del siglo XVIII, pues pasó de ser privilegio de la realeza y la alta nobleza a interpretarse en reuniones domesticas de la burguesía y en conciertos públicos. ${ }^{112}$ Una costumbre generalizada en España en tiempos de Carlos III desde 1787 fue el «concierto espiritual» de música profana e instrumental coetá-

107 González Valle, 2000.

108 Leza, 2014, 223-273.

109 Gómez Muntané, 2001; Caballero Fernández-Rufete, 1997; Fiorentino, 2008; Gallego, 1988, 58-66.

110 García Fraile, 2002

111 Gallego, 1988, 106.

112 Ibidem, 288. 
nea en los teatros de las grandes ciudades durante la cuaresma, en que estaba prohibido representar espectáculos escénicos, ${ }^{113}$ y que también podemos encontrar en México y Buenos Aires. ${ }^{114}$

En ámbito teatral, la ópera y la serenata italiana seria y cómica, la zarzuela y los géneros breves fueron los productos más demandados en el siglo XVIII. En su momento y sobre todo en la historiografía posterior se ha interpretado que la influencia italiana vino a provocar una colonización musical y una decadencia, aunque actualmente se valora más como un factor de modernización en la música española e hispanoamericana. ${ }^{115}$ En Sevilla las nuevas influencias vinieron de la mano de la visita de la corte en 1729-1733. Tras una prohibición moralizante de actividades teatrales que se prolongaba desde 1679, en 1761 se abrió el primer teatro de ópera italiana de Ribaltó en Sevilla bajo la protección de los asistentes ilustrados. ${ }^{116}$ Entre 1779 y 1793, volvió a estar prohibido el teatro, y entonces se instaló en Sevilla una nueva compañía de ópera italiana que habría de prosperar: la de Calderi y Sciomeri, ${ }_{117}^{17}$ que estuvo representando espectáculos distintos todos los días de la temporada teatral desde $1795 .{ }^{118}$ Más que a la ópera, la sociedad estaba acostumbrada a la música escénica que comportaban los dramas moralizantes, comedias, tonadillas escénicas, ${ }^{119}$ sainetes, zarzuelas, melólogos, volatines, bailes ${ }^{120}$ y pantomimas. ${ }^{121}$ Estos géneros breves casaron con la ópera ofreciéndose en la misma función teatral.

Por su parte, los bailes públicos de sociedad (aquellos a los que cualquier persona tenía acceso mediante la adquisición de una entrada) se celebraron ocasionalmente en el siglo XVIII, como alternativa ilustrada a los ritos tradicionales de excesos y música popular que caracterizaban el carnaval. Debemos integrarlos en el programa de dinamización cultural y musical que pusieron en marcha los ilustrados (en Sevilla el asistente Pablo de Olavide durante sus doce años de regencia, el cual celebraba veladas culturales en su propia casa). ${ }^{122}$ Los bailes disponían de varias orquestas

113 Ibidem, 315-321.

114 Marín, 2014, 475-477.

115 Carreras, 2000.

116 Moreno Mengíbar, 1998, 20; Aguilar Piñal, 1974, 37-51.

117 Plaza Orellana, 2007, passim.

118 Ibidem, 375-404. 2008.

119 La bibliografía principal sobre esta manifestación es: Subirá, 1933; Lolo Herranz, 2002 y

120 Mera, 2008.

121 González-Ariza, 2008.

122 Gutiérrez Cordero, 2008, 41. 
y maestros de danza. El repertorio, instrumental de danza, comprendía minués y contradanzas francesas. ${ }^{123}$ No fue un fenómeno muy arraigado debido a vaivenes políticos, de manera que solo se celebraron durante algunas temporadas. ${ }^{124}$

Amén de lo dicho, no se debe olvidar que existieron otros espacios para la música, menos documentados, tales como las funciones teatrales y musicales de los colegios, o las fiestas privadas populares de Triana en las que actuaban los artistas gitanos más célebres y demandados. ${ }^{125}$

En conjunto, Sevilla gozaba una vida musical religiosa y un calendario celebrativo tan ricos como los de otras ciudades peninsulares ${ }^{126}$ aunque no se pueda comparar con Madrid, y no en vano el siglo XVIII asiste a la multiplicación de sus capillas musicales parroquiales ${ }^{127}$ gracias a su condición de capital económica y la concentración de órdenes religiosas, cofradías e instituciones. La capilla catedralicia actuó a lo largo del siglo XVIII para al menos 38 instituciones, documentándose 350 intervenciones externas entre 1737 y $1738,{ }^{128}$ y para completar el panorama habría que sumarle las actividades de las otras capillas. El clima musical de la ciudad parece ser próspero en el siglo XVIII en comparación con otras ciudades de pequeño tamaño como Jaca, en la que se han documentado 325 actuaciones musicales externas de la capilla catedralicia (la única propiamente dicha que existía) en 1720-1800, ${ }^{129}$ pero no tan floreciente si lo comparamos con metrópolis comerciales vecinas como Cádiz, donde los violines se incorporaron a la capilla catedralicia en 1717, se vendían partituras de la música en boga en Europa en la librería Ulloa, ${ }^{130}$ se desarrolló la música instrumental guitarrística, y hubo tres teatros en funcionamiento en el siglo XVIII, representando espectáculos musicales españoles, franceses e italianos, y clausurados por reveses económicos y no por interdicciones morales. ${ }^{131}$ Después de Barcelona, fue la ciudad donde más floreció la ópera italiana en España. ${ }^{132}$

123 Bejarano Pellicer, 2009.

124 Plaza Orellana, 2007, 237.

125 Ibidem, 89-95.

126 Un estudio destacable sobre la vida musical de una ciudad española en el siglo XVIII es el siguiente: Marín, 2002, 197-214.

127 En Valencia también existieron varias capillas musicales en el siglo XVIII, según Bombi, 1995.

128 Isusi Fagoaga, 2003, I, 246-253.

129 Marín, 2002, 211.

130 Rivas, 1986, 3.

131 Díez Martínez, 2004, 55-64 y 504.

132 Martín Moreno, 1985a, 283. 
Hay estudios que demuestran el dinamismo en la recepción de música foránea y estilos modernos, incluso extranjera, en capitales cercanas como Cádiz ${ }^{133}$ y en pequeñas ciudades lejanas como Jaca ${ }^{134}$, lo cual invita a pensar que también debía existir en una gran ciudad como Sevilla. La proximidad de Cádiz como activo puerto atlántico debió de alentar algún tipo de influencias foráneas. Los intercambios de material musical y músicos que tuvieron lugar entre Sevilla y Cádiz (la ciudad española que encargó una composición al propio Haydn) sugieren una circulación de influencias y estilos musicales. ${ }^{135}$ No en vano el magisterio de capilla de la catedral de Cádiz se consideraba la antesala del de la de Sevilla. ${ }^{136}$

No obstante, tengamos en cuenta también que la pérdida de la Casa de Contratación en 1717 supuso un revés para la urbe hispalense que ocasionó su progresivo estancamiento económico y mermó sus relaciones internacionales, de modo que la capilla catedralicia redujo sus efectivos musicales. ${ }^{137}$ A los espectáculos escénicos (que comenzaron en 1761 y fueron periódicamente atacados e interrumpidos por consideraciones morales) no acudían ni las élites ni los sectores más rigoristas. ${ }^{138}$ Los indicios hacen pensar que a la abundancia de música barroca y religiosa se sumó una notable resistencia a las nuevas corrientes estilísticas y a los géneros profanos en general y escénicos en particular. Por lo tanto, Sevilla parece aquejada más de conservadurismo que de aislamiento.

\section{¿Cuál fue el papel de la música en la alameda?}

Por todo lo anterior, cabe preguntarse si verdaderamente la música fue un elemento importante en las alamedas, o si por el contrario pasó con frecuencia desapercibida. ¿Su fuerza de atracción fue lo bastante potente? ¿Constituyó una verdadera contribución a la creación de un espacio público interestamental?

A falta de otras pruebas documentales, el principal aval que sostiene esta afirmación es su perdurabilidad a través del tiempo. Como hemos visto, la documentación revela que la música en las alamedas no fue una

133 Ibidem, 464-485.

134 Marín, 2002, 255-303.

135 Díez Martínez, 2004, 506-507.

136 Rivas Pérez, 1986, 5.

137 Martín Moreno, 1985b, 183.

138 Plaza Orellana, 2007, 365-374. 
realidad que naciera en el siglo XVIII. Los propios veinticuatros sevillanos defendían la continuidad de la costumbre musical apelando a su antigüedad. ${ }^{139}$ Los paseos que fueron construidos antes de esas fechas (esto es, los de las capitales del siglo XVI, Sevilla y Madrid) ${ }^{140}$ gozaron de la misma presencia musical en el siglo XVI que en el XVIII, como delatan las fuentes narrativas y archivísticas.

La preeminencia de los instrumentos aerófonos continuó en estos espacios desde el siglo XVI, a pesar de las transformaciones organológicas que sustituyeron a los ministriles (tañedores de chirimías, cornetas negras, sacabuches, flautas y bajones) por clarineros. En el siglo de las luces las capillas de música religiosa se convirtieron en el refugio de estos instrumentos en extinción fuera de España, ${ }^{141}$ y no es extraño que también los concejos los mantuvieran, en tanto que solían ser los mismos individuos los que servían a la catedral y al ayuntamiento. La introducción de los instrumentos de cuerda jamás pudo hacer sombra a los aerófonos. De hecho, en la representación de los músicos de la alameda de Hércules en los azulejos del monasterio de la Encarnación de Osuna en 1780 siguen figurando instrumentistas de viento, y sabemos que sus herederos serán las bandas de viento y percusión del siglo XIX. La mayor potencia sonora de este tipo de instrumentación será siempre la más adecuada a las características del espacio abierto.

Ni siquiera el repertorio debió de cambiar de carácter (aunque no podamos comprobarlo), porque las copias de aerófonos de madera siempre vulgarizaron y difundieron las obras de los grandes compositores para las masas, de manera que desde antiguo constituyeron una correa de transmisión entre la música culta y la popular, al tañer adaptándose a ambientes muy diferentes en virtud de la variedad de sus clientes. ${ }^{142}$ La labor de democratización de la música que llevaron a cabo las bandas en el siglo XIX ya debió de tener un importante antecedente en la Edad Moderna en las copias de ministriles.

139 Márquez Redondo, 2010, v. 2, 903.

140 Nos consta que en el paseo de los Jerónimos en Madrid también en 1595 «se goza de gran deleite y gusto de la frescura del viento todas las tardes y noches del estío y de muchas buenas músicas». Lopezosa Aparicio, 2005a, 38.

141 Bordás, 2000, 208.

142 Kreitner, 2009, 273; Ruiz Jiménez, 2004, 236-238; Ruiz Jiménez, 1997, 54. Aunque estos autores hablan de los ministriles del siglo XVI, sus afirmaciones resultan válidas dada la ausencia de información sobre el tema durante el siglo XVIII y las pervivencias del repertorio y la figura de los ministriles a lo largo del tiempo. 
Por consiguiente, concluimos que si las estructuras musicales gozaron de tan larga vida en el ámbito de la alameda y demostraron tanta estabilidad, ello se debió a que entraron a formar parte de la identidad de aquel espacio, del clima de recreación y del paisaje sonoro del paseo. Aunque las fuentes no sean explícitas sobre la acogida o el efecto que provocaron en el público, las músicas ofrecidas en las alamedas debieron de cumplir satisfactoriamente las funciones que se les atribuyeron. De hecho, se imbricaron de tal modo en el escenario y sus actividades, que la exportación del modelo urbanístico por el Nuevo Mundo llevó a aparejada la del ejemplo musical. Ni el espacio de esparcimiento ni su ambientación musical fueron una novedad de la Ilustración, y por lo tanto rebasaron los límites cronológicos y los ámbitos geográficos de la misma, encontrando su máximo desarrollo en el siglo XIX.

Recibido el 18 de junio de 2015 Aceptado el 3 de septiembre de 2015

\section{Bibliografía}

Aguilar Piñal, Francisco: Bibliografía de autores españoles del siglo XVIII, Madrid, CSIC, 1981.

Aguilar Piñal, Francisco: Sevilla y el teatro en el siglo XVIII, Oviedo, Universidad de Oviedo, 1974.

Albardonedo Freire, Antonio José: El urbanismo de Sevilla durante el reinado de Felipe II, Sevilla, Guadalquivir, 2002.

Alén, María Pilar: «Controversias en torno a la teoría y la práctica musical en las capillas catedralicias españolas en el siglo XVIII», Quintana, 1, Santiago de Compostela, 2002, 143-151.

Añón, Carmen y Sancho, José Luis: Jardín y naturaleza en el reinado de Felipe II, Madrid, Unión Fenosa y Sociedad Estatal para la conmemoración de los centenarios de Felipe II y Carlos V, 1998.

Aplauso real, aclamación afectuosa, y obsequio reverente, que en lucido festejo de máscara joco seria consagraron los escolásticos alumnos del Colegio Mayor de Santo Thomás de Aquino [...] de la muy Noble y muy Leal Ciudad de Sevilla, en el día 2 de mayo de este año de 1742, al serenísimo señor Infante Cardenal Don Luis Jaime de Borbón y Farnese, Sevilla, Imprenta de los Recientes, 1742.

Aracil, Alfredo: Juego y artificio. Autómatas y otras ficciones en la cultura del Renacimiento a la Ilustración, Madrid, Cátedra, 1998, 257-295. 
Arana de Valflora, Fermín: Compendio histórico descriptivo de la muy noble y muy leal ciudad de Sevilla, metrópoli de Andalucía [1789], Edición facsímil del Colegio Oficial de Aparejadores y Arquitectos Técnicos de Sevilla, 2003.

Aroca Vicenti, Fernando: «De muladar a alameda: evolución de algunos espacios de recreo en el Jerez moderno y contemporáneo», Revista de Historia de Jerez, 10, Jerez, 2004, 125-145.

Astruells Moreno, Salvador: La banda municipal de Valencia y su aportación a la historia de la música valenciana, Tesis doctoral, Universidad de Valencia, 2003. Disponible en: http://hdl.handle.net/10803/9846

Bejarano Pellicer, Clara: «El baile de máscaras: una propuesta ilustrada para el carnaval», en Álvarez Santaló, L. C. (coord.), Estudios de Historia Moderna en homenaje al profesor Antonio García-Baquero, Sevilla, Universidad de Sevilla, 2009, 229-242.

Bejarano Pellicer, Clara: «La música en las fiestas municipales de verano en Sevilla en la Baja Modernidad», Nassarre. Revista aragonesa de musicología, 29, Zaragoza, 2013a, 45-76.

Bejarano Pellicer, Clara: El mercado de la música en la Sevilla del Siglo de Oro, Sevilla, Universidad de Sevilla, Fundación Focus-Abengoa, 2013b.

Bombi, Andrea: «La música en las festividades del Palacio Real de Valencia», Revista de Musicología, 18, 1-2, Madrid, 1995, 175-228.

Bombi, Andrea; Carreras, Juan José y Marín, Miguel Ángel (eds.): Música y cultura urbana en la Edad Moderna, Valencia, Universidad de Valencia, 2005.

Bosqued Lacambra, Pilar: «La Alameda de Fuenterrabía/Hondarribia. Cuatro siglos de jardinería pública», PARJAP: Revista de la Asociación Española de Parques y Jardines Públicos, 60, 2010, 6-15.

Bordás, Cristina: «Tradición e innovación en los instrumentos musicales», en Boyd, M. y Carreras López, J. J. (eds.), La música en España en el siglo XVIII, Cambridge, Cambridge University Press, 2000, 201-217.

Caballero Fernández-Rufete, Carmelo: «Miscent sacra profanis: música profana y teatral en los villancicos de la segunda mitad del siglo XVII", en Virgili, M. A.; Vega García-Luengos, G. y Caballero Fernández-Rufete, C. (eds.), Música y literatura en la Península Ibérica: 1600-1750, Valladolid, Sociedad «V Centenario del Tratado de Tordesillas», 1997, 50-64.

Cabeza Rodríguez, Antonio y Muñoz, Adelaida: «Algunos aspectos de la vida musical de Palencia en el siglo XIX: las bandas de música», Revista de Musicología, 14, 1-2, Madrid, 1991, 279-296.

Capdepón Verdú, Paulino: «La música municipal en Irún durante el siglo XIX: la creación de la banda de música», Nassarre, 27, Zaragoza, 2011, 201-246.

Carmona García, Juan Ignacio: Crónica urbana del malvivir (s. XIV-XVII). Insalubridad, desamparo y hambre en Sevilla, Sevilla, Universidad de Sevilla, 2000. 
Carreras, Juan José: «De Literes a Nebra: la música dramática entre la tradición y la modernidad», en Boyd, M. y Carreras, J. J. (eds.), La música en España en el siglo XVIII, Madrid, Cambridge University Press, 2000, 19-28.

Clares Clares, María Esperanza: «Bandas y música en la calle: una visión a través de la prensa en las ciudades de Murcia y Cartagena (1800-1875)», Revista de Musicología, 28, 1, Madrid, 2005, 543-562.

Daza Palacios, Salvador: Música y sociedad en Sanlúcar de Barrameda, Sevilla, Junta de Andalucía, 2010.

Díez Huerga, María Aurelia: «Salones, bailes y cafés: costumbres socio-musicales en el Madrid de la reina castiza (1833-1868)», Anuario musical, 61, Madrid, 2006, 189-210.

Díez Martínez, Marcelino: La música en Cádiz. La Catedral y su proyección urbana durante el siglo XVIII, Cádiz, Universidad y Diputación de Cádiz, 2004.

Durán Montero, María Antonia: «La Alameda de los Descalzos de Lima y su relación con las de Hércules de Sevilla y la del Prado de Valladolid», en Andalucía y América en el siglo XVII. Actas de las III Jornadas de Andalucía y América, Sevilla, Escuela de Estudios Hispano-Americanos, 1985, t. 2, 171-182.

El triunfo de la sabiduría sobre el error. Alegoría que representaron los estudiantes de la Real Universidad Literaria de Sevilla en el día 21 de abril de 1789 en la función pública, que con motivo de la proclamación de nuestro augusto monarca el señor Don Carlos IV dispuso el claustro y gremio de ella, Sevilla, Imprenta de Vázquez, Hidalgo y compañía, s/f. [1789].

Fernández Chaves, Manuel Francisco: «El agua en la Alameda de los Hércules en el siglo XVIII: gestión de un recurso para la organización del espacio», Archivo Hispalense, 273-275, Sevilla, 2007, 77-111.

Fernández Chaves, Manuel Francisco: Política y administración del abastecimiento de agua en Sevilla durante la Edad Moderna, Sevilla, Diputación Provincial, 2012, 174-178.

Fiorentino, Giuseppe: «La música de "hombres y mugeres que no saben de música": polifonía de tradición oral en el Renacimiento español», Revista de Musicología, 31, 1, Madrid, 2008, 9-39.

Gallego Roca, Francisco Javier: La casa de las chirimías, Madrid, Azur, 1983.

Gallego, Antonio: La música en tiempos de Carlos III, Madrid, Alianza, 1988.

García Fraile, Dámaso: «Las siestas como actividad musical en las iglesias hispanas durante el Antiguo Régimen», Nassarre, 18, 1-2, Zaragoza, 2002, 375436.

García Gómez, Francisco: Los orígenes del urbanismo moderno en Málaga: el paseo de la Alameda, Málaga, Universidad de Málaga, Colegio de Arquitectos, 1995, 54-55.

Gembero Ustárroz, María: «El contexto musical andaluz durante la estancia de la corte de Felipe V en Sevilla (1729-1733)», en Morales, N. y Quiles García, 
F. (eds.), Sevilla y corte. Las Artes y el Lustro Real (1729-1733), Madrid, Casa de Velázquez, 2010, 301-311.

Gil Arráez, Jorge: «De los instrumentos de guerra a las bandas de música. Una aproximación histórica sobre las primeras bandas de música del ejército español del siglo XVIII», Música. Revista del Real Conservatorio Superior de Música de Madrid, 21, Madrid, 2014, 33-55.

Gil, Manuel: Relación de la proclamación del rey nuestro señor don Carlos IIII, y fiestas con que la celebró la muy noble y muy leal ciudad de Sevilla, Madrid, Imprenta de la viuda de don Joaquín Ibarra, 1790.

Gimeno Arlanzón, Begoña: Las publicaciones periódicas musicales zaragozanas en la España de la Restauración (1883-1924): un estudio de la sociedad, cultura y actualidad artística locales, Tesis doctoral, Universidad de Zaragoza, 2010. Disponible en http://zaguan.unizar.es/record/5433/files/TESIS-2010053.pdf

Gómez Muntané, María del Carmen: «La polifonía vocal española del Renacimiento hacia el Barroco: el caso de los villancicos de Navidad», Nassarre, 17, Zaragoza, 2001, 77-114.

Gonzalbo Aizpuru, Pilar: «La vida social urbana del México colonial», en González Sánchez, Carlos Alberto y Vila Vilar, Enriqueta (comps.), Grafías del imaginario. Representaciones culturales en España y América (siglos XVI-XVIII), México, Fondo de Cultura Económica, 2003, 590-607.

González Valle, José Vicente: «Música litúrgica con acompañamiento orquestal, 1750-1800», en Boyd, M. y Carreras, J. J. (eds.), La música en España en el siglo XVIII, Madrid, Cambridge University Press, 2000, 67-86.

González-Ariza, Fernando: «Los bailes y pantomimas en Madrid en el siglo XVIII: escenografía y fuentes», Dicenda. Cuadernos de Filología Hispánica, 26, Madrid, 2008, 73-82.

Goycoolea Prado, Roberto: «Papel y significación urbana de los espacios para la música en la ciudad occidental», Política y Sociedad, 44, Madrid, 2007, 13 38.

Gutiérrez Cordero, María del Rosario: La música en la colegiata de San Salvador de Sevilla, Granada, Centro de Documentación Musical de Andalucía, 2008.

Gutiérrez, Ramón: Arquitectura y urbanismo en Iberoamérica, Madrid, Cátedra, 1983.

Isusi Fagoaga, Rosa: «Fiestas regias y celebraciones musicales durante el establecimiento de la Corte de Felipe V en Sevilla (1729-1733)», en Serrano, Eliseo (ed.), Felipe V y su tiempo. Congreso internacional, Zaragoza, Institución Fernando el Católico, 2004, I, 867-882.

Isusi Fagoaga, Rosa: La música en la catedral de Sevilla en el siglo XVIII: la obra de Pedro Rabassa y su difusión en España e Hispanoamérica, Granada, Universidad de Granada, 2003. 
Kenyon de Pascual, Beryl: «Clarines and trompetas: some further observations», Historic Brass Society Journal, 7, 1995, 100-106.

Kisby, Fiona (ed.): Music and musicians in Renaissance cities and towns, Cambridge, Cambridge University Press, 2001.

Kreitner, Kenneth: «The repertory of the Spanish cathedral band», Early Music, 37, 2, Oxford, 2009, 267-286.

León, Aurora: Iconografía y fiesta durante el lustro real (1729-1733), Sevilla, Diputación Provincial, 1990.

Leza, José Máximo (ed.): Historia de la música en España e Hispanoamérica, Madrid, Fondo de Cultura Económica de España, 2014.

Lolo Herranz, Begoña: «La tonadilla escénica, ese género maldito», Revista de musicología, 25, 2, Madrid, 2002, 439-469.

Lolo Herranz, Begoña: «Sainetes y tonadillas con música en el Madrid del siglo XVIII (1750-1760). Una revisión del género», en Álvarez Barrientos, J. y Lolo Herranz, B. (eds.), Teatro y música en España: los géneros breves en la segunda mitad del siglo XVIII, Madrid, CSIC, Universidad Autónoma, 2008, 41-62.

López Cobas, Lorena: «Las bandas de música en Galicia: aproximación al caso de la ciudad de A Coruña en el siglo XIX», Revista de Musicología, 31, 1, Madrid, 2008, 79-123.

Lopezosa Aparicio, Concepción: El paseo del Prado de Madrid. Arquitectura y desarrollo urbano en los siglos XVII y XVIII, Madrid, Fundación de Apoyo a la Historia del Arte Hispánico, 2005a.

Lopezosa Aparicio, Concepción: «Ocio y negocio. El jardín del Tívoli en el Paseo del Prado de Madrid», Anales de Historia del Arte, 15, Madrid, 2005b, 269-279.

Luque Azcona, Emilio José: «La conformación de nuevos espacios de sociabilidad: la Alameda de Paula y el Paseo de Extramuros de La Habana», en El municipio indiano: relaciones interétnicas, económicas y sociales. Homenaje a Luis Navarro García, Sevilla, Universidad de Sevilla, 2009, 369-381.

Mariana, Juan de: Tratado contra los juegos públicos [1609], Suárez García, José Luis (ed.), Granada, Universidad de Granada, 2004.

Marín, Miguel Ángel: Music on the margin. Urban musical life in eighteen century Jaca (Spain), Kassel, Reichenberger, 2002.

Marín, Miguel Ángel: «El sonido de una ciudad pequeña en tiempos de Felipe V», en Serrano, E. (ed.), Felipe $V$ y su tiempo, Zaragoza, Institución Fernando el Católico, 2004, II, 7-23.

Marín, Miguel Ángel: «El mercado de la música», en Leza, José Máximo (ed.), Historia de la música en España e Hispanoamérica, Madrid, Fondo de Cultura Económica de España, 2014, 439-484. 
Márquez Redondo, Ana Gloria: Sevilla ciudad y corte (1729-1733), Sevilla, Ayuntamiento de Sevilla, 1994.

Márquez Redondo, Ana Gloria: El Ayuntamiento de Sevilla en el siglo XVIII, Sevilla, Ayuntamiento de Sevilla, ICAS y Cajasol, 2010.

Martín Gaite, Carmen: Usos amorosos del dieciocho en España, Madrid, Siglo XXI, 1972.

Martín Moreno, Antonio: Historia de la música española. Vol. 4. El siglo XVIII, Madrid, Alianza, 1985a.

Martín Moreno, Antonio: Historia de la música andaluza, Granada, Biblioteca de la Cultura Andaluza, 1985b.

Matute y Gaviria, Justino: Anales eclesiásticos y seculares de la ciudad de Sevilla, Sevilla, Guadalquivir, 1997 [1796].

Méndez Rodríguez, Luis: «Bailes y fiestas de negros. Un estudio de su representación artística», Archivo Hispalense, 273-275, Sevilla, 2007, 397-412.

Mera, Guadalupe: «La danza, el baile, los saraos, la danza escénicas y los bailes populares. Notas y precisiones sobre su estado en la España ilustrada», en Álvarez Barrientos, J. y Lolo Herranz, B. (eds.), Teatro y música en España: los géneros breves en la segunda mitad del siglo XVIII, Madrid, CSIC, Universidad Autónoma, 2008, 459-480.

Merino Beato, María Dolores: Urbanismo y arquitectura de Valladolid en los siglos XVII y XVIII, Valladolid, Fundación Municipal de Cultura, 1989-1990.

Middleton, Richard: «Popular Music», en Sadie, Stanley (ed.): The New Grove Dictionary of Music and Musicians, 2. ${ }^{\mathrm{a}}$ ed., Londres, Macmillan, 2001.

Monroy y Silva, Cristóbal: La Alameda de Sevilla, y recato en el amor, Sevilla, Francisco de Leefdael, s/f. Biblioteca de la Universidad de Sevilla, A Mont 4/7/20.

Morales Folguera, José Miguel: «Jardines de Nueva España. La Alameda de Querétaro, 1798. Entre la modernidad y la tradición», Boletín de Arte, 10, Málaga, 1989, 197-222.

Morales, Nicolás: «Felipe V en Sevilla. Una corte y una música itinerantes (17291733)», en Morales, N. y Quiles García, F. (eds.), Sevilla y corte. Las Artes y el Lustro Real (1729-1733), Madrid, Casa de Velázquez, 2010, 271-299.

Moreno Mengíbar, Andrés: La ópera en Sevilla en el siglo XIX, Sevilla, Universidad de Sevilla, 1998.

Navarrete Pellicer, Sergio: «Las capillas de música de viento en Oaxaca en el siglo XIX», Heterofonía. Revista de investigación musical, 124, México, 2001, 9-27.

Nieto, María: «Los jardines del Buen Retiro de Madrid y el jardín "El Capricho" de la Alameda de Osuna. El paisaje y la escenografía del jardín», en Iglesias Gil, J. M. (ed.), Actas de los X cursos monográficos sobre el patrimonio histórico, Santander, Universidad de Cantabria, Ayuntamiento de Reinosa, 2000, 215-224. 
Ortiz de Sandoval, Gerónimo: Fábula heroica. Hércules, fundador de Sevilla. Celebración festiva al felicissimo natal del príncipe de las Asturias, nиеstro señor Luis I [...], Sevilla, Francisco de Leefdael, 1707.

Ortiz de Zúñiga, Diego: Anales eclesiásticos y seculares de la muy noble y muy leal ciudad de Sevilla, Sevilla, Guadalquivir, 1988 (original publicado en Madrid, Imprenta Real, Juan García Infançón, 1677).

Page, Carlos A.: «La exteriorización de nuevas formas de vida en la ciudad colonial. Las alamedas y el paseo público de Córdoba del Tucumán», Anales del Museo de América, 15, 2007, 123-140.

Plaza Orellana, Rocío: Los espectáculos escénicos en Sevilla bajo el gobierno de Godoy (1795-1808), Sevilla, Diputación Provincial, 2007.

Presas, Adela: «La edición musical de la imprenta real en el contexto cultural de la Ilustración», en Lolo, B. y Gosálvez, J. C. (coords.), Imprenta y edición musical en España (ss. XVIII-XX), Madrid, Universidad Autónoma, 2012, 145-166.

Quintana Moreno, Hugo José: «La música de salón en Colombia y Venezuela, vista a través de las publicaciones periódicas de la segunda mitad del siglo XIX y las primeras décadas del siglo XX: a propósito de un ejercicio de historia musical comparada», en Recasens Barberà, A. (dir.), A tres bandas. Mestizaje, sincretismo e hibridación en el espacio sonoro iberoamericano, Madrid, Akal, 2010, 91-102.

Rasch, Rudolf: «The internationalization o the music trade in the eighteen century», en Lolo, B. y Gosálvez, J. C. (coords.), Imprenta y edición musical en España (ss. XVIII-XX), Madrid, Universidad Autónoma, 2012, 35-64.

Raventós Freixa, Jordi: Manifestacions musicals a Barcelona a través de la festa: les entrades reials (segles XV-XVIII), Tesis doctoral, Universidad de Gerona 2006. Disponible en http://www.tdx.cat/handle/10803/7843.

Recio Mir, Álvaro: «Los maestros de hacer coches y su pugna con los pintores: un apunte sevillano de la dialéctica gremio-academia», Laboratorio de Arte, 18 , Sevilla, 2005, 355-370.

Recio Mir, Álvaro: «Una aproximación al gremio de sevillano de maestros de hacer coches: confluencias artísticas y rivalidades profesionales», en Morales Martínez, A. (coord.), Congreso Internacional Andalucía Barroca. Actas, Sevilla, Junta de Andalucía, 2009, v. 1, 405-416.

Rivas Pérez, José María: Aproximación a la música en Cádiz durante el siglo XVIII, Cádiz, Cuadernos de la Cátedra, 1986.

Roche, Daniel: Voitures, chevaux et attelages du XVIe au XVIIe siècle, París, Association por l'académie d'art équestre de Versailles, 2000.

Ruiz Jiménez, Juan: «Música y devoción en Granada (siglos XVI-XVIII): funcionamiento "extravagante" y tipología de plazas no asalariadas en las capillas musicales eclesiásticas de la ciudad», Anuario Musical, 52, 1997, 39-75. 


\section{CLARA BEJARANO PELLICER}

Ruiz Jiménez, Juan: «Ministriles y extravagantes en la celebración religiosa», en Grittiths, J. y Suárez-Pajares, J. (eds.), Políticas y prácticas musicales en el mundo de Felipe II. Estudios sobre la música en España, sus instituciones y sus territorios en la segunda mitad del siglo XVI, Madrid, ICCMU, 2004, 199-239.

Salinas, Jorge Ramón: «Música y cultura en Huesca durante la Restauración (1875-1902): a través de sus fuentes hemerográficas», AACA Digital: Revista de la Asociación Aragonesa de Críticos de Arte, 16, Zaragoza, 2011. http://www.aacadigital.com/contenido.php?idarticulo=532\&idrevista=23

Sánchez Huedo, Olga: La banda municipal de música de Albacete: Desde sus orígenes hasta la primera década del siglo XX, Tesis doctoral, Universidad de Salamanca, 2008. Disponible en http://gredos.usal.es/jspui/handle/10366/ 18375

Siemens Hernández, Lothar: «La valoración estética y sociológica de Manuel Alonso Ortega sobre los músicos de su época», Revista de Musicología, 8, Madrid, 1985, 135-138.

Smithers, Don L.: The Music and History of the Baroque Trumpet before 1721, Carbondale y Edwardsville, Southern Illinois University Press, 1933.

Strohm, Reinhard: Music in late medieval Bruges, Oxford, Clarendon, 1990.

Suárez Martos, Juan María: Música sacra barroca en la catedral hispalense, Tesis doctoral, Universidad de Sevilla, 2007.

Suárez-Pajares, Javier: «El auge de la guitarra moderna en España», en Boyd, M. y Carreras, J. J. (eds.), La música en España en el siglo XVIII, Madrid, Cambridge University Press, 2000, 251-270.

Subirá, José: La tonadilla escénica: sus obras y sus autores, Barcelona, Labor, 1933.

Virgili Blanquet, María Antonia: «Música y sociabilidad burguesa en Cuba: ocio e instrucción, 1833-1868», en Nagore, M. y Sánchez, V. (eds.), Allegro cum laude. Estudios musicológicos en homenaje a Emilio Casares, Madrid, Instituto Complutense de Ciencias Musicales, 2014, 471-484.

Waisman, Leonardo: «La música en la América española», en Leza, J. M. (ed.), Historia de la música en España e Hispanoamérica, Madrid, Fondo de Cultura Económica de España, 2014, 638-639.

Whitwell, David: The wind band and wind ensemble before 1500, Northridge, California, Winds Box 513, 1982.

Zúñiga, Lorenzo Baptista de: Annales ecclesiásticos y seglares de la muy noble y muy leal ciudad de Sevilla que comprehenden la olimpiada o lustra de la corte en ella, Sevilla, Florencio Blas y Quesada, 1748. 